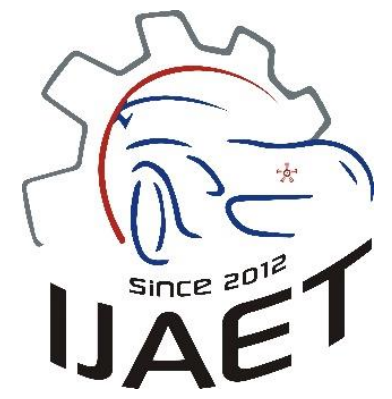

e-ISSN: 2146 - 9067

International Journal of Automotive

Engineering and Technologies

journal homepage:

https://dergipark.org.tr/en/pub/ijaet

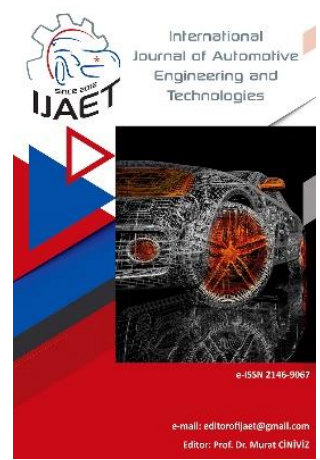

Original Research Article

\title{
The investigation of fuel properties of mixtures obtained by adding waste sunflower biodiesel and ethanol to euro diesel fuel
}

\begin{tabular}{|c|c|}
\hline \multicolumn{2}{|r|}{ Fatih Aydin ${ }^{1 *}$} \\
\hline \multicolumn{2}{|c|}{ 1, * Necmettin Erbakan University, Faculty of Engineering, Konya/Turkey } \\
\hline ARTICLE INFO & ABSTRACT \\
\hline $\begin{array}{l}\text { Orcid Numbers } \\
\text { 1. } 0000-0003-4828-0649\end{array}$ & $\begin{array}{l}\text { Energy production from waste in the world will be an indispensable factor for the } \\
\text { future of countries. Countries that can produce their own energy in the world will } \\
\text { be superior to other countries. In this study, waste sunflower oil was converted to }\end{array}$ \\
\hline Doi: 10.18245/ijaet.874772 & methyl ester by transesterification method and biodiesel was produced. A Ternary \\
\hline $\begin{array}{l}* \text { Corresponding author } \\
\text { fatihaydin@erbakan.edu.tr }\end{array}$ & $\begin{array}{l}\text { mixture was made from biodiesel, ethanol and euro diesel fuel obtained from } \\
\text { waste sunflower oil and test fuels were produced in the forms of D90B5E5, }\end{array}$ \\
\hline Received: Feb 04, 2020 & fuels at $40{ }^{0} \mathrm{C}$, density, water contents, $\mathrm{pH}$ values, color specifications, calorific \\
\hline Accepted: Mar 09, 2021 & values, cloud points, yield points, freezing, copper strip corrosion tests, CFPP tests \\
\hline Published: Oct 14, 2021 & $\begin{array}{l}\text { and cetane index tests were carried out and fuel properties were determined. As a } \\
\text { result of the tests, it was found out that the most suitable engine fuel mixture was }\end{array}$ \\
\hline $\begin{array}{l}\text { Published by Editorial Board } \\
\text { Members of IJAET }\end{array}$ & $\begin{array}{l}\text { D90B5E5. It can be used for internal combustion engines by adding ethanol to the } \\
\text { Biodiesel - Euro diesel fuel mixture and in this way, an environmentally friendly }\end{array}$ \\
\hline $\begin{array}{l}\text { (C) This article is distributed by } \\
\text { Turk Journal Park System under }\end{array}$ & $\begin{array}{l}\text { fuel mixture is obtained and energy conversion is achieved from waste. } \\
\text { Keywords: Biodiesel, Ethanol, Euro diesel, Fuel mixtures, Waste sunflower oil. }\end{array}$ \\
\hline
\end{tabular}

the CC 4.0 terms and conditions.

\section{Introduction}

Growing interest in sustainable development in the 21 st century is attracts more attention. In this context, issues like global warming and restrictions on oil reserves [1].

Biofuels are sourced from renewable sources and used as fuel. Biofuel production is important to reduce exhaust emissions in fossil fuels $[2,3]$. Nowadays biodiesel presents itself as an alternative to euro diesel fuel instead of oil originating from renewable raw materials and the fuel that biologically degradable [1]. Regarding emissions, net $\mathrm{CO}_{2}$ emissions was shown to be quite low, taking into account its renewable resource $[4,5]$.

Traditionally, Biodiesel is processed from different feedstocks like waste vegetable oil [6], animal fat [7], non-edible seeds oil [8, 9], waste oils and greases [10] and is converted into low viscous biofuel by means of catalyst assisted transesterification reaction using short-chain primary alcohols like methanol, ethanol as solvent [11].

Biodiesel is as thought an alternative fuel to diesel fuel with its high lubrication number, high flash point and suitable CFPP, which prolongs engine life with its good lubrication feature [12]. Biodiesel which is consumed in diesel engines is a renewable and environmentally friendly fuel [13].

The focus is on improved fuel economy, engine performance, minimal harmful exhaust 
emissions, and sustainable energy [14].

As the properties of biodiesel are very close to euro diesel fuel, diesel engines can use biodiesel without modification in many cases. The exhaust emissions of biodiesel fuel contain less particulate matter, hydrocarbon and carbon monoxide. Biodiesel contains higher cetane index and $10-11 \%$ oxygen by weight. In addition, it contains no Sulphur and no aromatics [15, 16]. Many studies have been conducted to find the best alternative fuel for internal combustion engines because of economic necessity and environmental impact of fossil fuel consumption [17, 18]. Biodiesel is an alternative fuel with a future for diesel engines $[19,20]$.

For clarification, biodiesel is not a true hydrocarbon product, it consists of alkyl esters of long-chain fatty acids and it is a transportation fuel that has gradually become popular over the past decade [21].

Today, the most common biofuels are ethanol and biodiesel. Ethanol can be produced from biomass by converting it into alcohol (ethanol) through the starch content of biomass raw materials, sugar and fermentation, fat and hydration of ethylene from other sources. The presence of oxygen in ethanol and biodiesel represents the potential to reduce emissions [22, 23]. The oxygen content reduces hydrocarbon emissions and carbon monoxide because these elements support a complete combustion [24]. Many studies have concentrated on the effects of biodiesel and their mixtures on exhaust emissions and engine performance [25, 26].

Jambulingam et al. [11] investigated the effect of waste animal oil biodiesel on the emission properties of the dominant fatty acid esters in the compression ignition engine. They produced biodiesel from waste animal oil through basecatalyzed transesterification, and in addition to biodiesel blend and straight diesel, they prepared test samples according to their availability and tested emission levels in a single-cylinder four-stroke compression ignition engine using a flue gas analyzer. As a result, they found that fatty acid esters were a pioneering task to understand the effect of biodiesel on the emission characteristics during combustion. Biodiesel obtained from waste vegetable oils is always considered as a potential resource. In addition, ethanol has potential as a fuel type. Because countries based on the strategy of reducing all environmental pollution in the world have drawn attention to renewable and alternative fuels.

A triple fuel mixture is a new type of fuel that is produced by adding certain proportions of ethanol and biodiesel to euro diesel fuel to improve the properties of euro diesel fuel. The benefits of triple fuel mixture can be explained as follows:

- Biodiesel in the triple fuel mixture is a very good lubricant and the deficiency of low sulphur euro diesel fuel with $10 \mathrm{ppm}$ sulphur ratio is eliminated.

- The viscosity of biodiesel, which is higher than that of euro diesel fuel, is reduced when mixed with ethanol-diesel.

- High Formaldehyde and Acetaldehydes emissions of ethanol is reduced by the biodiesel in the mixture.

- The disadvantage of ethanol and biodiesel with less energy than fossil fuels is prevented by using ripple fuel mixture.

- Combustion efficiency of the engine increases because triple fuel mixture is an oxygen fuel.

The aim of this study is, to determine the fuel properties of triple fuel mixture resulting from the mixing of biodiesel obtained from waste sunflower oil with ethanol and euro diesel fuel. The determination of fuel properties will shed light on the use of a triple mixture in diesel engines. The innovative aspect of this study is to investigate the usability of edible frying oil, which is harmful to the environment as waste, by converting it into biodiesel in internal combustion engines.

The article presents an experimental study on the main properties of diesel-waste oil biodieselethanol blends. The production of biodiesel from waste cooking oil eliminates the negative effects on the environment. In addition, as a result of its fuel properties, it has proved that it is possible to use these mixture fuels in internal combustion diesel engines.

\section{Materials and Method}

In this study, biodiesel was obtained from waste sunflower oil at Necmettin Erbakan University Energy Systems Engineering Department Biofuel Laboratory. The waste sunflower oil used in this study was obtained from the market 
methanol and $\mathrm{NaOH}$ were used in the production of biodiesel obtained from this oil. In addition, the transesterification method was used as the production method. For the oil was applied to a one-step transesterification method because the free fatty acid content of the oil was found to be less than one $[27,28]$. The catalyst concentration was adjusted to $6: 1$ with $0.4 \%$ by weight $(\mathrm{NaOH})$ and $20 \%$ methanol for transesterification. The reaction was stirred for 20 minutes by a magnetic stirrer at room temperature $\mathrm{NaOH}$ and methanol. Alcohol and catalyst solution were prepared continuously $750 \mathrm{rpm}$ at a temperature of $55^{\circ} \mathrm{C}$ and poured into the feed stock under a 60-minute period. Finally, the mixture was transferred to a separatory funnel and allowed to settle under gravity for 8 hours. When the reaction expired, the mixture was converted to glycerol and biodiesel. Glycerol was seated at the base and removed from the system. Crude biodiesel and distilled water were kept constant at $50{ }^{\circ} \mathrm{C}$ and $25 \%$ by volume of distilled water was used to wash the crude biodiesel. The mixture was then rested for approximately 8 hours to allow the water to settle. Decomposed water was removed with a funnel. The temperature of the washed biodiesel was raised to $125^{\circ} \mathrm{C}$ for 1.5 hours with a heated magnetic stirrer. In this way, biodiesel (methyl ester) was obtained. The produced reactor has a cylinder inner with diameter of 250 $\mathrm{mm}$ and a cylinder with a length of $640 \mathrm{~mm}$, electric motor, thermostat controlled, one filling valve and two discharge valves, a mixer and a capacity of 30 liters.

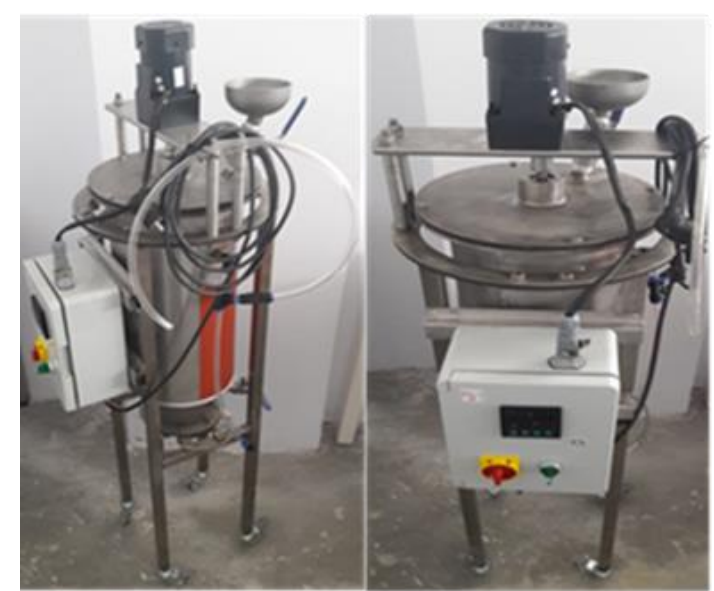

Figure 1. Reactor

Euro diesel fuel was obtained from the BP oil company. Fuel samples used in the experiments were prepared volumetrically. No decomposition was seen in the samples. Samples prepared for the experiments were kept in glass bottles with airtight screw caps. Glass bottles are heat resistant, $20 \mathrm{~cm}$ high, $10 \mathrm{~cm}$ in diameter. Four different test fuels were formed with the mixtures of euro diesel fuel, waste sunflower oil biodiesel and ethanol. The fuel obtained by the addition of 5\% ethanol and 5\% waste sunflower oil biodiesel to euro diesel fuel volumetrically was called D90B5E5, the fuel obtained by the addition of $10 \%$ ethanol and $10 \%$ waste sunflower oil biodiesel to euro diesel fuel volumetrically was called D80B10E10, the fuel obtained by the addition of $15 \%$ ethanol and $15 \%$ waste sunflower oil biodiesel to euro diesel fuel volumetrically was called D70B15E15and the fuel obtained by the addition of $20 \%$ ethanol and $20 \%$ waste sunflower oil biodiesel to euro diesel fuel volumetrically was called D60B20E20. Since the boiling point of ethanol was 78 degrees, the ethanol ratio in the triple fuel mixture did not exceed $20 \%$. In the study, while the main fuel was diesel fuel, the ethanol and biodiesel ratio was prepared in the same amount by volume. Also Julabo brand Corio $\mathrm{Cd}$ model device with temperature degree accuracy \pm 0.03 and operating temperature between 20 and $150{ }^{\circ} \mathrm{C}$ was used in the measurement of viscosity of fuels. The device can be measured viscosity according to ASTM D 445, DIN 51550 and ISO 3104 standards.

Technical Characteristics of Fuel Property Tester; Trademark and measuring standards, measurement ranges and accuracy are given in Table 2.

Error Bars to give a general idea of how accurate measurement helps to show the estimated error or uncertainty. This is done through the use of notation, the original chart, and the marks drawn on the data points. To visualize this information, slashes are drawn towards the point extending from the center of the data point Error Bars were drawn. The length of the error bar helps you reveal the uncertainty of a data point.

\section{Results and Discussion}

\subsection{Density}

It is the mass of a unit volume of a substance at a given temperature and pressure $\left(15{ }^{\circ} \mathrm{C}\right.$ and $101.325 \mathrm{kPa}$ ). Density is one of the features that makes it easy and quick to distinguish various fuels and oils. 
Table 1. Analysis results

\begin{tabular}{|c|c|c|c|c|c|c|c|c|c|c|}
\hline \multirow{3}{*}{ Characteristic } & \multirow{3}{*}{$\begin{array}{l}\text { The } \\
\text { Units }\end{array}$} & \multirow{3}{*}{$\begin{array}{c}\mathrm{D}_{90} \mathrm{~B}_{5} \\
\mathrm{E}_{5}\end{array}$} & \multirow{3}{*}{$\begin{array}{c}\mathrm{D}_{80} \mathrm{~B}_{10} \\
\mathrm{E}_{10}\end{array}$} & \multirow{3}{*}{$\begin{array}{c}\mathrm{D}_{70} \mathrm{~B}_{15} \\
\mathrm{E}_{15}\end{array}$} & \multirow{3}{*}{$\begin{array}{c}\mathrm{D}_{60} \mathrm{~B}_{20} \\
\mathrm{E}_{20}\end{array}$} & \multirow{3}{*}{$\begin{array}{c}\text { Waste } \\
\text { Sunflower } \\
\text { Biodiesel } \\
\text { Fuel }\end{array}$} & \multirow{3}{*}{$\begin{array}{c}\text { Ethanol } \\
\text { Fuel }\end{array}$} & \multirow{3}{*}{$\begin{array}{c}\text { Euro } \\
\text { Diesel } \\
\text { Fuel }\end{array}$} & \multicolumn{2}{|c|}{ Limiting Value } \\
\hline & & & & & & & & & $\begin{array}{c}\text { TS EN } \\
590\end{array}$ & $\begin{array}{l}\text { TS EN } \\
14214\end{array}$ \\
\hline & & & & & & & & & Diesel & $\begin{array}{c}\text { Biodie } \\
\text { sel }\end{array}$ \\
\hline $\begin{array}{l}\text { Kinematic } \\
\text { Viscosity } \\
\left(40^{\circ} \mathrm{C}\right)\end{array}$ & $\mathrm{mm}^{2} / \mathrm{s}$ & 2.471 & 2.245 & 2.169 & 2.341 & 4.716 & 1.268 & 3.065 & $2-4.5$ & $3.5-5$ \\
\hline $\begin{array}{l}\text { Density } \\
\left(15^{\circ} \mathrm{C}\right)\end{array}$ & $\mathrm{g} / \mathrm{cm}^{3}$ & 0.832 & 0.833 & 0.832 & 0.832 & 0.882 & 0.789 & 0.833 & $\begin{array}{c}0.82- \\
0.84\end{array}$ & $\begin{array}{c}0.86- \\
0.90\end{array}$ \\
\hline $\begin{array}{l}\text { Water } \\
\text { Content }\end{array}$ & ppm & 178.5 & 253.4 & 328.9 & 402.9 & 198.6 & 372.3 & 34.5 & 200 & 500 \\
\hline $\mathrm{pH}$ & - & 4.83 & 4.79 & 5.02 & 5.25 & 4.15 & 6.09 & 4.02 & -------- & -------- \\
\hline $\begin{array}{l}\text { Color } \\
\text { Determination }\end{array}$ & ASTM & $<0.5$ & $<0.5$ & $<0.5$ & $<0.5$ & 0.5 & 0.5 & 1.2 & ------- & ------- \\
\hline $\begin{array}{l}\text { Calorific } \\
\text { Value }\end{array}$ & $\mathrm{kJ} / \mathrm{kg}$ & 42332 & 41459 & 40585 & 39712 & 39350 & 29676 & 41276 & ------- & -------- \\
\hline $\begin{array}{l}\text { Cloud } \\
\text { Point }\end{array}$ & ${ }^{\circ} \mathrm{C}$ & -4.3 & -4.54 & -4.7 & -4.83 & 1.7 & -------- & -8.1 & -------- & ------- \\
\hline $\begin{array}{l}\text { Pour } \\
\text { Point }\end{array}$ & ${ }^{\circ} \mathrm{C}$ & -9.4 & -9.52 & -11.1 & -11.9 & -0.9 & ------- & -14 & ------- & ------- \\
\hline Freezing & ${ }^{\circ} \mathrm{C}$ & -20 & -21 & -22 & -23 & -6 & $<-20$ & -20 & ------- & -------- \\
\hline CFPP & ${ }^{\circ} \mathrm{C}$ & -16 & -15 & -17 & -15 & -5 & $<-20$ & -17 & -20 & -------- \\
\hline $\begin{array}{ll}\text { Copper } & \text { Strip } \\
\text { Corrosion } & \end{array}$ & _ & $1 \mathrm{a}$ & $1 \mathrm{a}$ & $1 \mathrm{a}$ & $1 \mathrm{a}$ & $1 \mathrm{a}$ & $1 \mathrm{a}$ & $1 \mathrm{a}$ & No:1 & No:1 \\
\hline Cetane Index & - & 50.9 & 48.6 & 46.8 & 45.1 & 55.2 & ------- & 51 & 51 & -------- \\
\hline
\end{tabular}

Table 2. Technical characteristics of fuel property tester

\begin{tabular}{|c|c|c|c|c|}
\hline Property & Device Trademark & $\begin{array}{l}\text { Measurement } \\
\text { Accuracy }\end{array}$ & $\begin{array}{l}\text { Measuring } \\
\text { Range }\end{array}$ & Standard \\
\hline $\begin{array}{l}\text { Kinematic Viscosity } \\
\text { Measuring Device }\end{array}$ & Koehler / K23377 & \pm 0.01 & $25-150{ }^{0} \mathrm{C}$ & ASTM D 445 \\
\hline Density Measuring Device & Kem Kyoto / DA-130N & \pm 0.0001 & $0-40{ }^{0} \mathrm{C}$ & ASTM D 4052 \\
\hline $\begin{array}{l}\text { Water Content } \\
\text { Measurement Device }\end{array}$ & $\begin{array}{c}\text { Kem Kyoto Electronic } \\
\text { MKC-501 }\end{array}$ & \pm 0.01 & $5-35{ }^{0} \mathrm{C}$ & ASTM D 2709 \\
\hline $\mathrm{pH}$ Meter & $\begin{array}{c}\text { Hanna Intruments / } \\
\text { HI8314 }\end{array}$ & \pm 0.01 & $0-14 \mathrm{pH}$ & ASTM D 5464 \\
\hline $\begin{array}{ll}\text { Automatic } & \text { Color } \\
\text { Measuring Device } & \end{array}$ & Lovibont / PFX195 & --------- & $0,5-8$ units & ASTM D 1500 \\
\hline $\begin{array}{l}\text { Flash Point Determination } \\
\text { Device }\end{array}$ & Koehler / K16270 & \pm 0.01 & $0-370^{\circ} \mathrm{C}$ & ASTM D 93 \\
\hline Calorimeter Device & Ika & \pm 0.0001 & 0 - 40000 joule & ASTM D 240 \\
\hline $\begin{array}{l}\text { Cloud, Yield and Freezing } \\
\text { Tester }\end{array}$ & Koehler / K46000 & \pm 0.01 & $(-69)-0{ }^{0} \mathrm{C}$ & ASTM D 97 \\
\hline $\begin{array}{l}\text { Cold Filter Plugging Point } \\
\text { Measurement Device }\end{array}$ & Tanaka / AFP-102 & \pm 0.01 & $(-60)-0{ }^{0} \mathrm{C}$ & ASTM D 6371 \\
\hline $\begin{array}{l}\text { Copper Strip Corrosion } \\
\text { Test }\end{array}$ & Koehler / K25330 & \pm 0.01 & $0-190{ }^{\circ} \mathrm{C}$ & ASTM D 6074 \\
\hline Cetane Index Device & Shatox SX-100M & \pm 0.5 & $20-100$ & ASTM D 613 \\
\hline Chronometer & Taksun & \pm 0.1 & ------------ & --------------- \\
\hline
\end{tabular}


Examining test results, D80B10E10 fuel has a higher density than other test fuels, but, the density values of all test fuels were within the limit values used that used in diesel engines. As shown in Table 1, the reason for this was that, the density of the biodiesel is high and the density of ethanol is low.

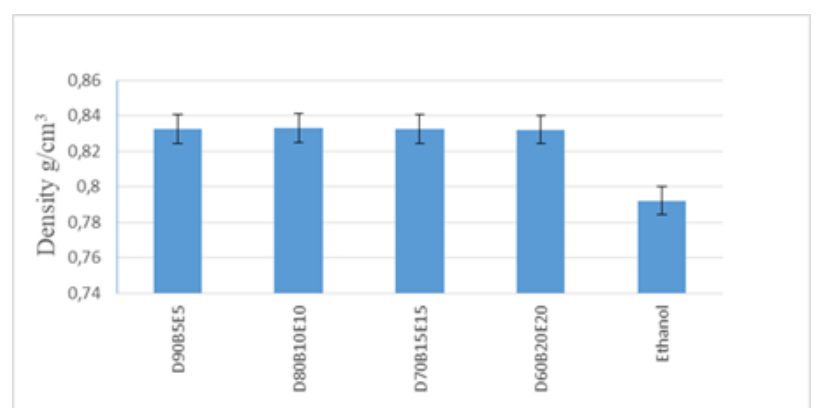

Figure 2. Density test results of fuel mixes and ethanol

\subsection{Kinematic viscosity at $40^{\circ} \mathrm{C}$}

Viscosity is a measure of the resistance of liquids to flow. This feature is also called the internal friction of the fluid. The viscosity value should be low enough to allow the fuel to flow easily even at low operating temperatures. Examining test results, it was seen that the kinematic viscosity all test fuels at $40{ }^{0} \mathrm{C}$ were within the limit values used in diesel engines. The reason for this was that, as shown in Table 1 , the kinematic viscosity of the biodiesel is high and the kinematic viscosity of ethanol is low.

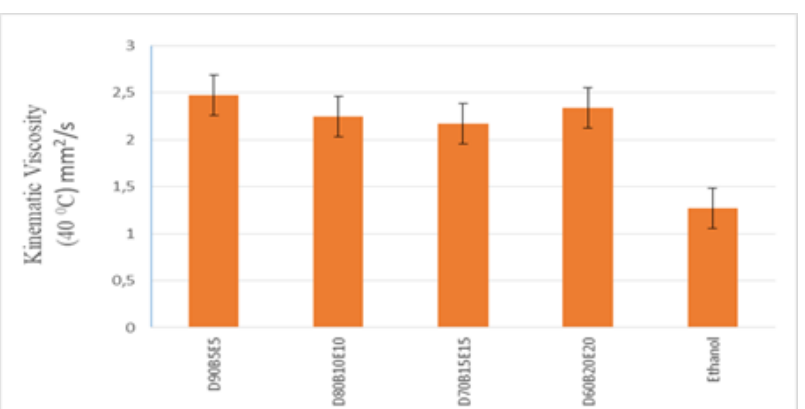

Figure 3. Kinematic viscosity test results of fuel mixes and ethanol at $40^{\circ} \mathrm{C}$

\subsection{Water Content}

Examining test results, it was found that the water content of D60B20E20 fuel was higher than other test fuels, but the water content values of all test fuels were within the limit values that used in diesel engines. The reason for this was that it was due to the excess of ethanol content in the D60B20E20 fuel as shown in Table 1.

\subsection{PH}

Examining test results, the $\mathrm{pH}$ of D60B20E20 fuel was higher than other test fuels. As shown in Table 1, the reason for this was that it was due to the excess of ethanol content in the D60B20E20 fuel. However, the $\mathrm{pH}$ values of all the test fuels were below 7 and they were acidic. In this regard, all test fuels were within the limit values used in diesel engines in terms of $\mathrm{pH}$ value.

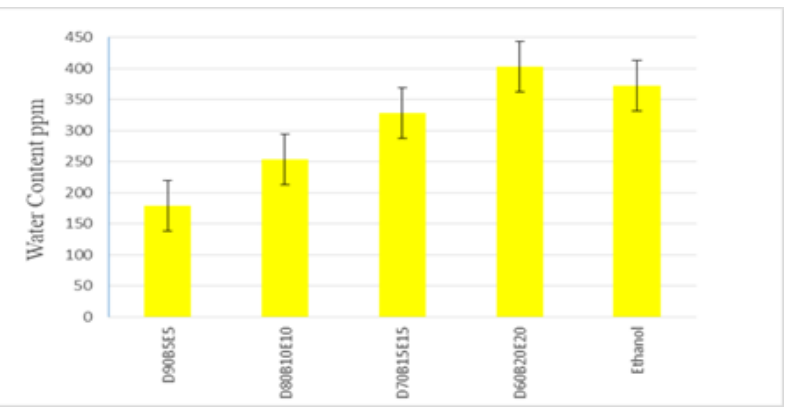

Figure 4. Water Content test results of fuel mixes and ethanol

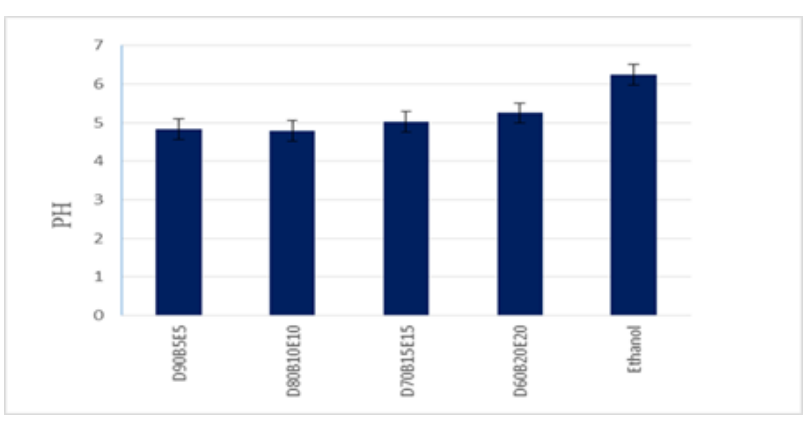

Figure 5. $\mathrm{pH}$ test results of fuel mixes and ethanol

\subsection{Color Specification}

When the color specification test results suggest that equivalent results were obtained in all fuels. This is a common situation for biodiesel and ethanol fuel mixtures.

\subsection{Calorific Values}

Calorific value is an indicator of the amount of energy that can be obtained from fuels. When the test results are analyzed, D90B5E5 the calorific value of the fuel was found to be higher than the other test fuel. As shown in Table 1, the reason for this was that the cetane index of D90B5E5 fuel was higher than the other mixtures. When the cetane index was high, the engine worked silently, and it was effective for easy starting of the engine and increased combustion efficiency.

\subsection{Cloud Point}

Cloud point is expressed as a fog consisting of wax crystals or the first temperature at which the cloud is observed when the liquid is cooled under certain conditions. Examining test results, 
the cloud point value of D60B20E20 was lower than the other test fuels. This is advantageous for the engine to operate in cold conditions. The low cloud point was due to the excess of ethanol content in the D60B20E20 fuel.

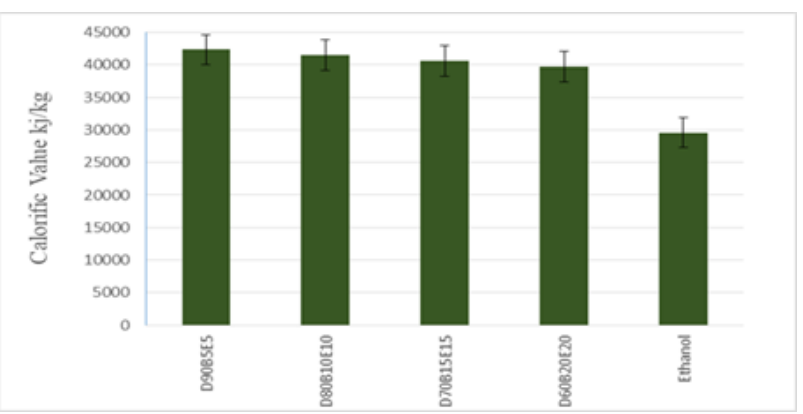

Figure 6. Calorific values test results of fuel mixes and ethanol

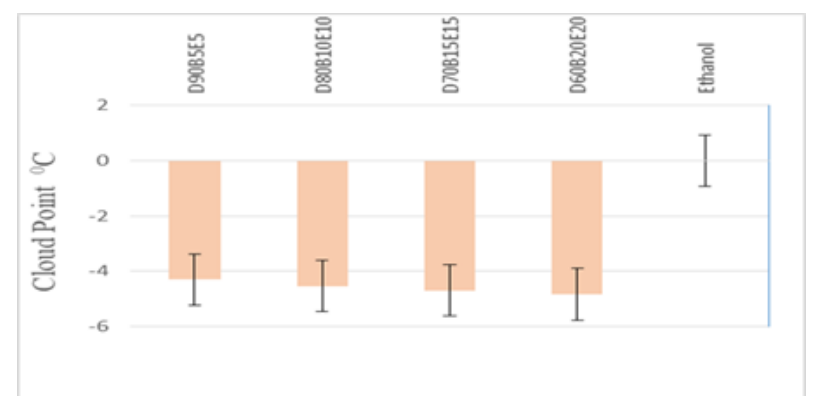

Figure 7. Cloud point test results of fuel mixes and ethanol

\subsection{Pour Point}

When the liquid continues to cool for a while, the value of the temperature when the liquid does not flow visibly is determined as the Pour Point. Examining test results, the pour point value of D60B20E20 fuel was lower than the other test fuels. This is advantageous for the engine to operate in cold conditions. The low yield point value resulted from the excess of ethanol content in D60B20E20.

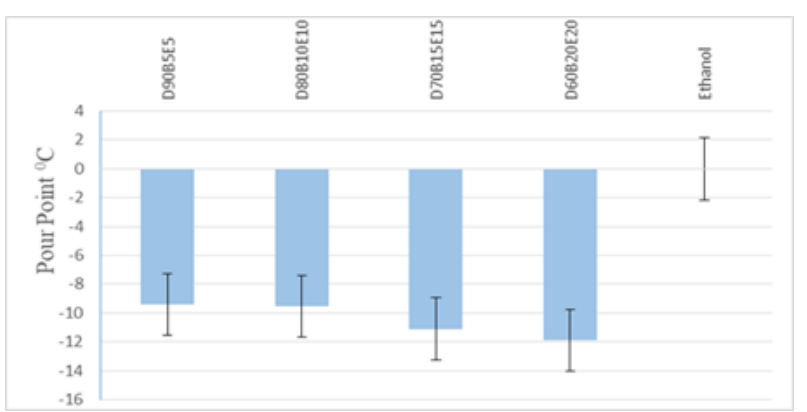

Figure 8. Pour point of the test fuel

\subsection{Freezing}

It is determined as the point where the liquid completely loses its fluidity. Examining test results, the freezing of the D60B20E20 fuel was lower than the other test fuels. This is advantageous for the engine to operate in cold conditions. The low freezing was due to the excess of ethanol content in D60B20E20 fuel.

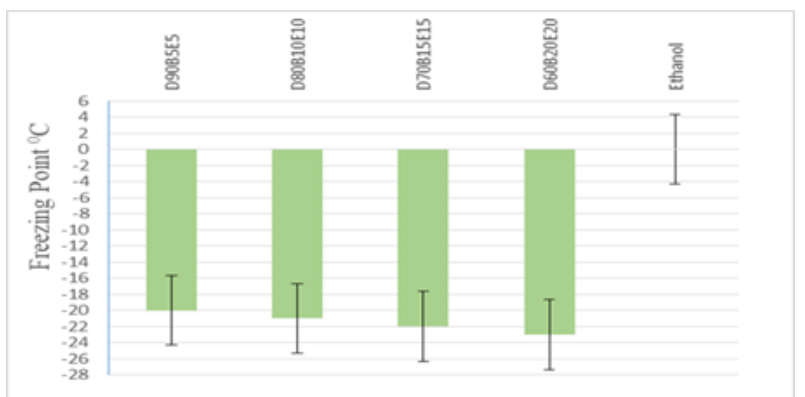

Figure 9. Freezing test results of fuel mixes and ethanol

\subsection{0. (Cfpp)}

It indicates the temperature of the fuel suitable for operation in the fuel filter. Examining test results, it was seen that the cold filter plugging point values of all fuels were within the limit values used in diesel engines. As shown in Table 1 , the reason for this was that the freezing temperature of the biodiesel is low and the freezing temperature of ethanol is high.

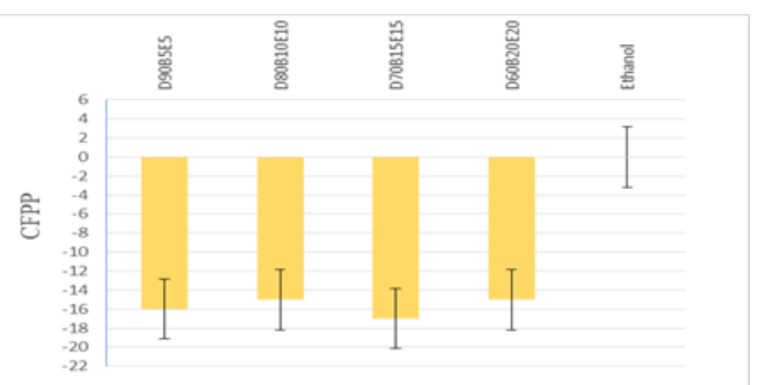

Figure 10. Cold filter plugging point test results of fuel mixes and ethanol

\subsection{Copper Strip Corrosion}

Copper strip corrosion test results of fuels are "1 a" and the values obtained are shown with graphics. This is a common situation for biodiesel and ethanol fuel mixtures.

\subsection{Cetane Index}

Cetane index; It is a measure that shows the ability of diesel fuel to ignite itself. Examining test results, it was found that the cetane index value of D90B5E5 fuel was higher than other test fuels. High cetane index was effective in increasing the combustion efficiency of the engine. This is due to the increase in the number of cetane biodiesel fuel. The fact that D90B5E5 fuel is equivalent to euro diesel fuel in terms of cetane index shows that it can be easily used in diesel engines.

In the literature, Bayindirli and Celik [29], this 
study, n-hexane and n-hexadecane were added to diesel fuel (D0) by volumes of $4,12 \%$, and $20 \%$. With respect to D0 fuel, in DHD20 and DHX20 fuels engine torque increased by $1.60 \%$ and $1.32 \%$, respectively, while the brake specific fuel consumption decreased by $3.12 \%$ and $1.98 \%$, respectively. Maximum cylinder pressures and heat release rate values of the ingredient added fuels increased. It was seen that NOx emissions increased while $\mathrm{HC}, \mathrm{CO}$, and soot emissions decreased with an increasing contribution ratio.

Çelik, et al., [30], this study includes the experimental evaluation of performance, combustion, and emission characteristics of cottonseed and grapeseed biodiesels and blends containing bioethanol in a diesel engine with different engine speeds at full load. While the brake power and torque values were reduced as the rate of bioethanol increased, additionally specific fuel consumption, maximum cylinder pressure, heat release and ignition delay also increased. Reviewing the emission results, carbon monoxide and total hydrocarbon emissions increased as bioethanol rate increased, nitrogen oxides and smoke emissions were reduced.

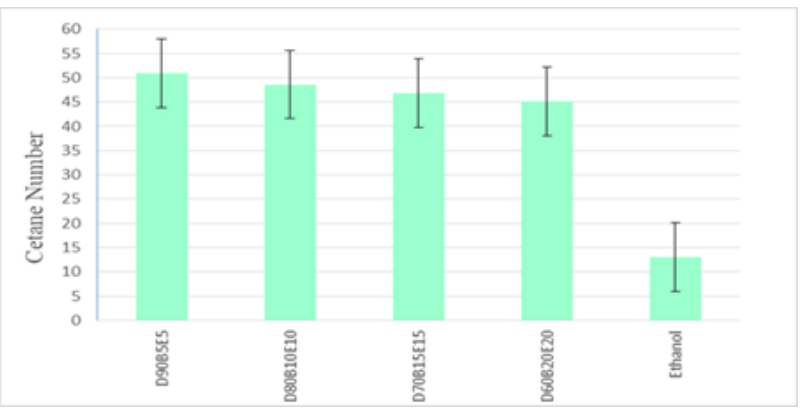

Figure 11. Cetane index test results of fuel mixes and ethanol

\section{Conclusions}

In this study, waste sunflower oil was converted to methyl ester by transesterification method and biodiesel production was performed. A Ternary mixture was made from biodiesel, ethanol and euro diesel fuel obtained from waste sunflower oil and test fuels were produced in the forms of D90B5E5, D80B10E10, D70B15E15 and D60B20E20. The kinematic viscosities of the test fuels at $40{ }^{\circ} \mathrm{C}$, density, water contents, $\mathrm{pH}$ values, color specifications, calorific values, cloud points, pour points, freezing, cetane index tests, copper strip corrosion test and the cold filter plugging point test were carried out and fuel properties were determined. By Teoh, et al., [31], addition of ethanol to $20 \%$ coconut biodiesel blends was found appropriate and minimizes biodiesel related problems. In particular, $5 \%$ and $10 \%$ ethanol by volume were added separately to the B20 mixture to compare their performance. Overall, experimental results proved that the B20E10 mixture showed great improvements in the diesel engine, so ethanol is a suitable fuel additive for coconut biodiesel mixtures. Similarly, they saw an improvement in motor fuels.

As a result of this work, it was concluded that the most appropriate engine fuel mixture was D90B5E5 in terms of fuel characteristics since the cetane index and calorific value of that fuel were higher than the other fuels and CFPP values were lower than the other fuels. These fuel mixtures can be used in internal combustion diesel engines without any modification on the engine.

\section{References}

1. Rodrigues, J.S., Valle, C.P., Uchoa, A.F.J., Ramos, D.M., Ponte, F.A.F., Rios, M.A.S., Malveria, J.Q. and Ricardo, N.M.P., (2020), Comparative Study of Synthetic and Natural Antioxidants on Theoxidative Stability of Biodiesel from Tilapia Oil, Renewable Energy, Volume 156, Pages 1100-1106.

2. Ryan L., Convery F. and Ferreira S., (2006), Stimulating the Use of Biofuels in the European Union: Implications for Climate Change Policy, Energy Policy, Volume 34, Issue 17, Pages 3184-3194.

3. Madheshiya, A. K. and Vedrtnam, A., (2018), Energy Exergy Analysis of Biodiesel Fuels Produced from Waste Cooking Oil and Mustard Oil, Fuel, 214, 386-408.

4. Carraretto, C., Macor. A., Mirandola, A., Stoppato, A. and Tonon, S., (2004), Biodiesel as alternative fuel: Experimental analysis and energetic evaluations, Energy, Volume 29, Issues 12-15, Pages 2195-2211.

5. Granados, M.L., Poves, M.,D., Z., Alonso, D., M., Mariscal, R., Galisteo, F., C., Tost, R.M., Santamarı, J. and Fierro, J.L.G., (2007), Biodiesel from sunflower oil by using activated calcium oxide, Applied Catalysis B: Environmental, Volume 73, Pages 317-326.

6. Ray, S. K., and Prakash, O. (2019). 
Biodiesel Extracted from Waste Vegetable Oil as an Alternative Fuel for Diesel Engine: Performance Evaluation of Kirlosker $5 \mathrm{~kW}$ Engine. Singapore: Springer.

7. Kirubakaran, M., and Selvan, V. A. M. (2018). A comprehensive review of low cost biodiesel production from waste chicken fat. Renew. Sus. Ener. Rev. 82, 390-401. Doi: 10.1016/j.rser.2017.09.039.

8. Hosseini, S. E., and Wahid, M. A. (2012). Necessity of biodiesel utilization as a source of renewable energy in Malaysia. Renew. Sustain. Energy Rev. 16, 5732-5740. Doi: 10.1016/j.rser.2012.05.025.

9. Palani, S., Srinivasan, G. R., and Ranjitha, J. (2017). Biodiesel production from the seeds of Mimusops elengi using potassium aluminium silicate as novel catalyst. Inno. Ener. Res. 6:165. doi: 10.4172/2576-1463.1000165.

10. Tran, N. N., Tišma, M., Budžaki, S., McMurchie, E. J., Gonzalez, O. M. M., Hessel, V., et al. (2018). Scale-up and economic analysis of biodiesel production from recycled grease trap waste. App. Energ. 229, 142-150. doi: 10.1016/j.apenergy.2018.07.106.

11. Jambulingam R., Shankar V., Palani S. and Srinivasan G.R., (2019), Effect of Dominant Fatty Acid Esters on Emission Characteristics of Waste Animal Fat Biodiesel in CI Engine, Front. Energy Res. https://doi.org/10.3389/fenrg.2019.00063.

12. Graboski, M.S. and McCormick, R., L., (1998), Combustion of fat and vegetable oil derived fuels in diesel engines, Progress in Energy and Combustion Science, Volume 24, Issue 2, Pages 125-164.

13. Nystrom, R., Sadiktsis, I., Ahmed, T. M., Westerholm, R., Koegler, J.H., Blomberg, A., Sandstrom, T. and Boman, C., (2016), Physical and Chemical Properties of RME Biodiesel Exhaust Particles without Engine Modifications, Fuel, 186, 261-269.

14. Otchere, P., Pan, J., Fan, B., Chen, W. and Lu, Y., (2021), Recent Studies of Fuels Used in Wankel Rotary Engines, Journal of Energy Resources Technology, 143(3): 030801. 15. Karaosmanoglu F., Kurt G. and Ozaktas T., (2000), Direct Use of Sunflower Oil as a Compression Ignition Engine Fuel, Energy Sources, 22, 659-672.

16. Canakci M. and Van Gerpen J. H., (2001), Biodiesel Production from Oils and Fats
With High Free Fatty Acids, Transaction of the ASAE, Vol,44 (6), 1429-1436.

17. Hajjari, M., Tabatabaei, M., Aghbashlo, M. and Ghanavati, H., (2017), A Review on the Prospects of Sustainable Biodiesel Production: A Global Scenario with an Emphasis on WasteOil Biodiesel Utilization, Renewable and Sustainable Energy Reviews, Volume 72, Pages 445-464.

18. Yesilyurt, M.K. and Arslan, M., (2019), Analysis of the fuel injection pressure effects on energy and exergy efficiencies of a diesel engine operating with biodiesel, Biofuels, Volume 10, Number 5, Pages 643-655.

19. Babazadeh, R., (2017), Optimal Design and Planning of Biodiesel Supply Chain Considering Non-Edible Feedstock, Renewable and Sustainable Energy Reviews, Volume 75, Pages 1089-1100.

20. Mahmudul H.M., Hagos F.Y., Mamat, R., Abdul Adam, A., Ishak, W.F.W. and Alenezi, R., (2017), Production, Characterization and Performance of Biodiesel as an Alternative Fuel in Diesel Engines-A Review, Renewable and Sustainable Energy Reviews, Volume 72, Pages 497-509.

21. Speight J.G., (2019), Handbook of Industrial Hydrocarbon Processes, Second Edition, Gulf Professional Publishing, Elsevier, Oxford, United Kingdom, Hydrocarbons from Crude Oil, Chapter 3, Page 125.

22. Bertoli C., Del Giacomo N. and Beatrice C., (1997), Diesel Combustion Improvements by the Use of Oxygenated Synthetic Fuels, Society of Automotive Engineers, 972972.

23. Miyamoto N., Ogawa H., Nurun N.A., Obata K. and Arima T., (1998), Smokeless, Low NOx, High Thermal Efficiency, and Low Noise Diesel Combustion with Oxygenated Agents as Main Fuel, Society of Automotive Engineers 980506.

24. Nabi N., Shahadat M., Z., Rahman S. and Beg R., A.. (2004), Behavior of Diesel Combustion and Exhaust Emission with Neat Diesel Fuel and Diesel Biodiesel Blends, Society of Automotive Engineers 01-3034.

25. Dorado M., P., Ballesteros E., Arnal J., Gomez J. and Gimenez F., J., L., (2003 a), Testing Waste Olive Oil Methyl Ester as a Fuel in a Diesel Engine, Energy Fuel, 17(6):15601565.

26. Dorado M.P., Ballesteros E., Arnal J., 
Gomez J. and Lopez F., (2003 b), Exhaust Emissions from a Diesel Engine Fueled With Transesterified Waste Olive Oil, Fuel, 82(11): 1311-1315.

27. Goyal P., Sharma M.P. and Jain S., (2013), Optimization of Transesterification of Jatropha Curcas Oil to Biodiesel using Response Surface Methodology and its Adulteration with Kerosene, Journal of Materials and Environmental Science, Volume 4, Number 2, Pages 277-284.

28. Jeyalakshmi P. and Subramanian R., (2013), The Application of Response Surface 28ethodology for the Optimization of Pretreatment Process Parameters of Paradise Seed (Simarouba Glauca) Oil, Energy Source Part A: Recovery, Utilization, and Environmental Effects, Volume 35, Issue 22, Pages 2087-2095.

29. Bayindirli, C. and Celik, M., (2019), Investigation of combustion and emission characteristics of $n$-hexane and n-hexadecane additives in diesel fuel, Journal of Mechanical Science and Technology, Volume 33, Issue 4, Pages 1937-1946.

30. Çelik, M., Örs, İ., Bayindirli, C. and Demiralp, M., (2017), Experimental investigation of impact of addition of bioethanol in different biodiesels, on performance, combustion and emission characteristics, Journal of Mechanical Science and Technology, Volume 31, Issue 11, Pages 5581-5592.

31. Teoh, Y.H., Yu, K.H., How, H.G. and Nyugen, H.T., (2019), Experimental Investigation of Performance, Emission and Combustion Characteristics of a Common-Rail Diesel Engine Fuelled with Bioethanol as a Fuel Additive in Coconut Oil Biodiesel Blends, Energies Volume 12, Issue 10, 1954, Pages 117. 